\title{
Effect of early feed restriction on myofibre types and expression of growth-related genes in the gastrocnemius muscle of crossbred broiler chickens
}

\author{
Yue $\mathrm{Li}^{1}$, Lixia Yuan ${ }^{1}$, Xiaojing Yang ${ }^{1}$, Yingdong $\mathrm{Ni}^{1}$, Dong $\mathrm{Xia}^{1}$, Stephan Barth ${ }^{2}$, Roland Grossmann ${ }^{3}$ \\ and Ru-Qian Zhao ${ }^{1 *}$ \\ ${ }^{1}$ Key Laboratory of Animal Physiology and Biochemistry, Nanjing Agricultural University, Nanjing 210095, P. R. China \\ ${ }^{2}$ Institute of Nutritional Physiology, Federal Research Centre for Nutrition and Food (BEEL), 76131 Karlsruhe, Germany \\ ${ }^{3}$ Institute for Animal Science, Federal Research Center of Agriculture (FAL), Mariensee, 31535 Neustadt, Germany
}

(Received 27 July 2006 - Revised 17 January 2007 - Accepted 17 January 2007)

\begin{abstract}
The purpose of this study was to investigate the immediate and long-term effects of early feed restriction (ER) on morphology and gene expression of lateral gastrocnemius muscle. Newly hatched crossbred broiler chickens were allocated into control and ER groups, the latter being free-fed on alternate days from hatch to 14 days of age (14 d), followed by ad libitum feeding as the control group until $63 \mathrm{~d}$. The lateral gastrocnemius muscle was taken at 14 and $63 \mathrm{~d}$, respectively for myofibre typing by both myosin ATPase staining and relative quantification of myosin heavy chain (MyHC) mRNA for slow-twitch (SM), red fast-twitch (FRM) and white fast-twitch (FWM) myofibres. The body weight and lateral gastrocnemius weight were significantly lower in the ER group, accompanied by significantly reduced serum triiodothyronine. The ER group exhibited significantly higher SM and FRM MyHC expression at $14 \mathrm{~d}$, but lower SM expression at $63 \mathrm{~d}$. Myosin ATPase staining revealed a similar pattern. The percentage of SM was higher at $14 \mathrm{~d}$ while lower at $63 \mathrm{~d}$ in the ER group. These morphological changes were accompanied by changes of mRNA expression for growth-related genes. The ER group expressed lower insulin-like growth factoar I (IGF-I) and higher IGF-I receptor (IGF-IR) at $14 \mathrm{~d}$, yet significantly increased growth hormone receptor and IGF-IR mRNA at $63 \mathrm{~d}$. These results indicate that ER may delay the slow to fast myofibre conversion as an immediate effect, but would result in a lower percentage of slow fibres owing to compensatory growth in the long term, which involves changes of mRNA expression for the growth-related genes in the muscle.
\end{abstract}

Feed restriction: Myosin heavy chain: Myofibre types: Gene expression: Chicken

Nutritional and metabolic exposure during critical periods of early development can have a long-term programming effect on health in adulthood (Demmelmair et al. 2006). This socalled 'nutritional or metabolic programming' has been described not only in mammals (de Moura \& Passos, 2005; Langley-Evans et al. 2005; Wu et al. 2006), but also in avian species. A large number of studies have been done in chicken to investigate the long-term effect of early nutritional manipulation on body and organ growth (Deaton, 1995; Kwakkel et al. 1998; Lee \& Leeson, 2001), digestion (Palo et al. 1995a,b; Pinheiro et al. 2004), reproduction (Goerzen et al. 1996), immunity (Khajavi et al. 2003), lipid metabolism (Zhong et al. 1995), and metabolic disorders (Acar et al. 1995; Su et al. 1999). Early feed restriction (ER) has been reported recently to influence satellite cell mitotic activity (Moore et al. 2005a,b), implying a possible long-term effect of early nutrition on skeletal muscle development in the chicken.
Skeletal muscle accounts for $40-50 \%$ of the body weight and contributes to the regulation of metabolic homeostasis of the body. Skeletal muscle consists of various types of myofibres with different metabolic profiles, contractile properties, as well as biochemical and biophysical characteristics, such as fibre size, colour, glycogen and lipid content (Ashmore \& Doerr, 1971). Slow-twitch myofibres (SM) are the smallest, oxidative fibres with red colour, high lipid content and many mitochondria, whereas white fast-twitch fibres (FWM) are the largest glycolytic fibres possessing high glycogen content and few mitochondria. Red fast-twitch myofibres (FRM) are intermediate oxidative-glycolytic fibres that are similar to SM in colour but resemble FWM in their contractile property, possessing both aerobic and anaerobic metabolic capabilities. Recently, myofibre-type composition of skeletal muscle has attracted great attention both in human health and animal production, owing to its close association with insulin sensitivity in mammals (Hickey et al. 1995; Korach-Andre et al. 2005)

\footnotetext{
Abbreviations: ER, early feed restriction; FRM, red fast-twitch myofibres; FWM, white fast-twitch myofibres; GH, growth hormone; GHR, growth hormone receptor; IGF, insulin-like growth factor; IGF-IR, type 1 IGF receptor; MyHC, myosin heavy chain; SM, slow-twitch myofibres; $\mathrm{T}_{3}$, triiodothyronine; $\mathrm{T}_{4}$, thyroxine.

* Corresponding author: Dr Ru-Qian Zhao, fax 00862584398669, email yzwj@public1.ptt.js.cn
} 
and its significance for lean-mass deposition and meat quality in meat-producing animals (Maltin et al. 2003), respectively. However, the long-term effect of early nutrition on skeletal muscle growth and myofibre type in poultry has not been reported.

Since myofibres undergo a highly regulated process of fibre conversion and hypertrophy which contributes to lean-mass deposition and metabolic status of the organism in the postnatal period, we hypothesized that early nutritional deficiency would affect myofibre-type composition, and this influence could be carried over through later life after a long term of ad libitum feeding. The acting mechanism may involve growth-related genes expressed in the muscle that respond to the early nutritional deficiency and participate in the regulation of myofibre-type conversion and myofibre hypertrophy.

The objectives of the present study were, therefore, to observe the immediate and long-term effects of ER on body and muscle growth, as well as the myofibre composition with both histochemical and molecular typing, and to explore the associated changes of mRNA expression for growthrelated genes in the muscle, employing crossbred broiler chickens as the experimental model.

\section{Materials and methods}

\section{Animals and experimental design}

Newly hatched San Huang chicks (a crossbred local broiler breed) were purchased from a commercial hatchery (Wen's Group, Guangdong, China) and allocated randomly into the control and the ER groups ( $n$ 40/group). The diets used in the experiment were formulated according to the nutritional requirements of the breed recommended by the breeding company (Table 1). Chickens in the control group were fed ad libitum for the whole period of investigation, while the ER group were subjected to feed restriction with feed provided on alternate days from hatch to 14 days of age (14 d), followed by ad libitum feeding until the end of the experiment at $63 \mathrm{~d}$ when chickens reached the marketing age.

The body weight of chickens was recorded weekly after being fasted overnight ( $n$ 40/group in first 2 weeks and $n$ 20/group after 14d). Feed consumption was recorded weekly. At $14 \mathrm{~d}$ and $63 \mathrm{~d}$ respectively, 10 chickens were randomly selected from each group and sacrificed for blood and tissue sampling. One side of the lateral gastrocnemius muscle was weighed and rapidly frozen in liquid $\mathrm{N}_{2}$, then

Table 1. Nutritional composition of the basal diet

\begin{tabular}{lcc}
\hline & \multicolumn{2}{c}{ Age (weeks) } \\
\cline { 2 - 3 } Nutritional composition & $1-4$ & $5-9$ \\
\hline Crude protein (\%) & 21.5 & 19.5 \\
Metabolizable energy (MJ/kg) & 13.01 & 13.82 \\
$\mathrm{NaCl}(\%)$ & 0.37 & 0.33 \\
$\mathrm{Ca} \mathrm{( \% )}$ & 0.96 & 0.85 \\
$\mathrm{P}(\%)$ & 0.45 & 0.43 \\
Lysine (\%) & 1.25 & 1.13 \\
Methionine (\%) & 0.62 & 0.56 \\
Methionine + Cysteine (\%) & 0.95 & 0.87 \\
\hline
\end{tabular}

stored at $-80^{\circ} \mathrm{C}$ until RNA isolation, while the other side was taken for measuring the cross-sectional areas and densities of SM, FRM and FWM with myosin ATPase staining.

The experiment was undertaken following the guidelines of the regional animal ethics committee.

\section{Radioimmunoassay for serum hormone levels}

The serum concentrations of total triiodothyronine $\left(\mathrm{T}_{3}\right)$ and thyroxine $\left(\mathrm{T}_{4}\right)$ were measured with RIA using commercial kits purchased from the Shanghai Institute of Biological Products (Shanghai, China). The kits were validated for measuring avian serum samples (Zhao et al. 2004a).

\section{Histochemical analysis}

Myosin ATPase staining was applied to identify myofibre type and to measure myofibre size. Briefly, muscle blocks were excised perpendicularly to the direction of the myofibres. Freshly excised muscles were mounted on corks coated with gum tragacanth, rapidly frozen in liquid $\mathrm{N}_{2}$, and then stored at $-80^{\circ} \mathrm{C}$. Serial tissue sections of $10 \mu \mathrm{m}$ thickness were prepared with a cryostat at $-20^{\circ} \mathrm{C}$. Sections were washed twice for $1 \mathrm{~min}$ each with $18 \mathrm{mmol} \mathrm{CaCl} / 1$ and $100 \mathrm{mmol}$ Tris-HCl/l (pH 7·3; pre-rinse solution) and pre-incubated for $5 \mathrm{~min}$ at $\mathrm{pH} 10.4$ (100 mmol glycine/1, $1 \% \mathrm{CaCl}_{2}, 3.7 \%$ formaldehyde) at room temperature. The sections were then washed twice for $30 \mathrm{~s}$ each time with pre-rinse solution prior to incubation in $18 \mathrm{mmol} \mathrm{CaCl}_{2} / 1,20 \mathrm{mmol}$ glycine $/ 1$, and $0.025 \mathrm{mmol} \mathrm{ATP} / 1$ (pH 9.4) for $1 \mathrm{~h} 45 \mathrm{~min}$ at $37^{\circ} \mathrm{C}$. Afterwards sections were washed four times in $1 \% \mathrm{CaCl}_{2}$ wash solution and then rinsed in $2 \% \mathrm{CoCl}_{2}$ for $4 \mathrm{~min}$ at room temperature. Subsequently sections were washed in distilled water four times for $20 \mathrm{~s}$ each then stained in a $1 \%$ Azure Stain for $30 \mathrm{~s}$. The stained sections were finally rinsed continuously under tap water for $10 \mathrm{~min}$ and washed in distilled water for $5 \mathrm{~min}$, then dehydrated in ascending series of ethanol concentrations, delipidated in a solution of xylene-absolute ethanol (1: 1, v/v) and coverslipped. Six to seven fascicles (containing about 400-500 myofibres) were randomly selected from five serial sections of each sample using light microscopy (Olympus BH-2, Tokyo, Japan) with camera (JVC, Yokohama, Japan) at magnification 200, and the mean percentages of SM, FRM and FWM myofibres were calculated using image processing software (Image-Pro Plus 4.5, Silver Spring, MD, USA). The fibre type was determined as described by Wegner et al. (2000). FWM are stained dark blue, FRM are stained light blue, whereas SM are nonstained (Hoogenraad et al. 1979).

\section{$R N A$ extraction and reverse transcription}

Total RNA was extracted from the tissue samples with a singlestep method of RNA extraction by acid guanidinium thiocyanate-phenol-chloroform (Chomczynski \& Sacchi, 1987). Total RNA concentration was then quantified by measuring the absorbance at $260 \mathrm{~nm}$ in a photometer (Eppendorf Biophotometer, Hamburg, Germany). Ratios of absorption (260:280 nm) of all preparations were between 1.8 and 2.0. Aliquots of RNA samples were subjected to electrophoresis through a $1.4 \%$ agarose-formaldehyde gel to verify their integrity. 
Total RNA $(2 \mu \mathrm{g})$ was reverse transcribed by incubation at $37^{\circ} \mathrm{C}$ for $1 \mathrm{~h}$ in a $25 \mu \mathrm{l}$ mixture consisting of $100 \mathrm{U}$ M-MLV RT (Promega, Madison, WI, USA), 8 U RNase inhibitor (Promega), $21 \mu \mathrm{mol}$ random primers/l (6 bp), $50 \mathrm{mmol}$ Tris- $\mathrm{HCl} / 1$ (pH 8.3), 3 mmol $\mathrm{MgCl}_{2} / 1,75 \mathrm{mmol} \mathrm{KCl} / 1,10 \mathrm{mmol} \mathrm{DDT} / 1$ and $0.8 \mathrm{mmol}$ each $\mathrm{dNTP} / \mathrm{l}$ (Promega). The reaction was terminated by heating at $95^{\circ} \mathrm{C}$ for $5 \mathrm{~min}$ and quickly cooling on ice.

\section{Semi-quantitative $R T-P C R$}

The mRNA expression of SM, FRM, FWM, myosin heavy chain (MyHC) and growth hormone receptor (GHR), insulin-like growth factor-I (IGF-I) and type-I IGF receptor (IGF-IR) mRNA was quantified relative to $18 \mathrm{~S}$ rRNA, using the Quantum RNA 18S Internal Standards kit (catalogue no. 1716, Ambion Inc., Austin, TX, USA), containing primers and competitors, for normalizing variations in pipetting and amplification. RT reaction mix $(2 \mu \mathrm{l})$ was used for PCR in a final volume of $25 \mu \mathrm{l}$ containing $0.5 \mathrm{U}$ Taq DNA polymerase (Promega), $5 \mathrm{mmol}$ Tris-HCl/l (pH 9.0), $10 \mathrm{mmol} \mathrm{NaCl} / \mathrm{l}$, $0.1 \mathrm{mmol}$ DDT/l, $0.01 \mathrm{mmol}$ EDTA/l, $5 \%$ (w/v) glycerol, $0.1 \%(w / v)$ Triton X-100, $0.2 \mathrm{mmol}$ each dNTP/l, $1.6 \mathrm{mmol}$ $\mathrm{MgCl}_{2} / \mathrm{l}, 0.4 \mu \mathrm{mol} / \mathrm{l}$ each primer pair specific for three types of MyHC, GHR and IGF-IR, respectively, together with $0.4 \mu \mathrm{mol} 18 \mathrm{~S}$ rRNA primers/l and competitors in proportions optimized for each target gene. Each target gene was co-amplified with $18 \mathrm{~S}$ rRNA in the same reaction except IGF-I which was amplified separately from $18 \mathrm{~S}$ rRNA in duplicate. The primers for MyHC and growth-related genes were designed using Primer Premier 5.0 and were synthesized by Yinjun Biotech. Ltd (Shanghai, China). The nucleotide sequences of these primers and the PCR conditions set for respective genes are shown in Table 2. The PCR products from each reaction were sent to Haojia Biotech. Ltd (Shanghai, China) for sequencing to verify the specificity. The reported sequences matched exactly those published in GenBank. Different controls were set to monitor the possible contaminations of genomic DNA and environment DNA at the stage of both RT and PCR. The pooled samples made by mixing equal quantity of total cDNA from all samples were used for optimizing the PCR condition and normalizing the intra-assay variations. The cycles of PCR were determined to ensure that the amplifications were terminated within the linear range for quantification.
All samples were included in the same run of RT-PCR and repeated at least three times. Both RT and PCR were performed in a Gene Amp PCR System 9600 (Perkin Elmer, Norwalk, CT, USA).

\section{Quantification of PCR products}

An aliquot $(10-20 \mu \mathrm{l})$ of PCR products was analyzed by electrophoresis on $2 \%$ agarose gels. The gels were stained with ethidium bromide and photographed with a digital camera. The net intensities of individual bands were measured using Kodak Digital Science 1D software (Eastman Kodak Company, Rochester, NY, USA). The ratios of net intensity of target genes to $18 \mathrm{~S}$ rRNA were used to represent the relative levels of target gene expression.

\section{Statistical analysis}

The results were expressed as mean values with their standard errors and differences were considered significant when $P<0 \cdot 05$, tested by $t$ test for independent samples. The correlations among the mRNA abundances, body weight and lateral gastrocnemius muscle weight were tested by Pearson's correlation coefficients with correlate, bivariate analysis. All statistical analyses were performed with SPSS 11.0 for windows (StatSoft, Inc., Tulsa, OK, USA).

\section{Results}

Growth performance

The growth performance and feed consumption in control and ER groups across the observation period are summarized in Table 3. Chickens in the ER group consumed considerably less feed, the average weekly feed intake being 48.5 and $62.0 \%$ lower compared with that of the control group in the first and second week, respectively. The feed intake in the ER group remained low for 6 weeks thereafter under ad libitum feeding. The ER resulted in chickens with significantly lower body weight compared with their control counterparts throughout the experiment. Relative growth rate in the ER group, represented by percentage of daily body weight gain (average daily body weight gain relative to the initial body weight), was much lower under feed restriction in the first two weeks

Table 2. Nucleotide sequences of specific primers and PCR conditions

\begin{tabular}{|c|c|c|c|c|}
\hline Target genes & GenBank accession & PCR products (bp) & Primer sequences & PCR conditions \\
\hline SM & $\begin{array}{l}\text { GenBank } \\
\text { U85022, U85023 }\end{array}$ & 331 & $\begin{array}{l}\text { F: } 5^{\prime} \text {-aacgccgcaacaacct }-3^{\prime} \\
\text { R: } 5^{\prime} \text {-ttcttcttcatccgctcc }-3^{\prime}\end{array}$ & $\begin{array}{l}94^{\circ} \mathrm{C}, 30 \mathrm{~s} ; 57^{\circ} \mathrm{C}, 30 \mathrm{~s} ; 72^{\circ} \mathrm{C}, 30 \mathrm{~s} \\
27 \text { cycles }\end{array}$ \\
\hline FRM & $\begin{array}{l}\text { GenBank } \\
\text { NM_204228, M74086 }\end{array}$ & 334 & $\begin{array}{l}F: 5^{\prime} \text {-atctggtggacaaactgc }-3^{\prime} \\
R: 5^{\prime} \text {-aatctatggtctttattctct }-3^{\prime}\end{array}$ & $\begin{array}{l}94^{\circ} \mathrm{C}, 30 \mathrm{~s} ; 53^{\circ} \mathrm{C}, 30 \mathrm{~s} ; 72^{\circ} \mathrm{C}, 30 \mathrm{~s} \\
23 \text { cycles }\end{array}$ \\
\hline FWM & $\begin{array}{l}\text { GenBank } \\
\text { M74087 }\end{array}$ & 380 & $\begin{array}{l}F: 5^{\prime} \text {-gtgaagggtgtacgcaagt }-3^{\prime} \\
R: 5^{\prime} \text {-atagatgacaatgacataaaaaagcaacac- } 3^{\prime}\end{array}$ & $\begin{array}{l}94^{\circ} \mathrm{C}, 30 \mathrm{~s} ; 57^{\circ} \mathrm{C}, 30 \mathrm{~s} ; 72^{\circ} \mathrm{C}, 30 \mathrm{~s} \\
19 \text { cycles }\end{array}$ \\
\hline GH-R & $\begin{array}{l}\text { GenBank } \\
\text { NM_001001293 }\end{array}$ & 345 & $\begin{array}{l}\text { F: } 5^{\prime} \text {-ttacttcaacacatcctacacc }-3^{\prime} \\
\text { R: } 5^{\prime} \text {-tcataatctcttcccatcttca }-3^{\prime}\end{array}$ & $\begin{array}{l}94^{\circ} \mathrm{C}, 30 \mathrm{~s} ; 53^{\circ} \mathrm{C}, 30 \mathrm{~s} ; 72^{\circ} \mathrm{C}, 30 \mathrm{~s} \\
27 \text { cycles }\end{array}$ \\
\hline IGF-IR & $\begin{array}{l}\text { GenBank } \\
\text { AJ223164 }\end{array}$ & 397 & $\begin{array}{l}F: 5^{\prime} \text {-gtacttcagtgcttcggatgtg }-3^{\prime} \\
\text { R: } 5^{\prime} \text {-cttcttcagagttggaggtgct }-3^{\prime}\end{array}$ & $\begin{array}{l}94^{\circ} \mathrm{C}, 30 \mathrm{~s} ; 53^{\circ} \mathrm{C}, 30 \mathrm{~s} ; 72^{\circ} \mathrm{C}, 30 \mathrm{~s} \\
27 \text { cycles }\end{array}$ \\
\hline IGF-I & $\begin{array}{l}\text { GenBank } \\
\text { M32791 }\end{array}$ & 191 & $\begin{array}{l}\text { F: } 5^{\prime} \text {-catttcttctaccttggc }-3^{\prime} \\
\text { R: } 5^{\prime} \text {-tcatccactattcccttg }-3^{\prime}\end{array}$ & $\begin{array}{l}94^{\circ} \mathrm{C}, 30 \mathrm{~s} ; 53^{\circ} \mathrm{C}, 30 \mathrm{~s} ; 72^{\circ} \mathrm{C}, 30 \mathrm{~s} \\
29 \text { cycles }\end{array}$ \\
\hline
\end{tabular}

SM, slow-twitch myofibres; FRM, red fast-twitch myofibres; FWM, white fast-twitch myofibres; GHR, growth hormone receptor; IGF-I, insulin-like growth factor I; IGF-IR, type I IGF receptor. 
Table 3. Effect of early feed restriction (ER) on body weight, relative body weight gain and average weekly feed intake of crossbred broiler chickens (Values are means with their standard errors)

\begin{tabular}{|c|c|c|c|c|c|c|c|c|}
\hline \multirow{3}{*}{$\begin{array}{l}\text { Age } \\
\text { (weeks) }\end{array}$} & \multicolumn{4}{|c|}{ Body weight (g) } & \multirow{2}{*}{\multicolumn{2}{|c|}{$\begin{array}{l}\text { Relative daily body } \\
\text { weight gain (\%) }\end{array}$}} & \multirow{2}{*}{\multicolumn{2}{|c|}{$\begin{array}{l}\text { Average weekly } \\
\text { feed intake }(\mathrm{g})\end{array}$}} \\
\hline & \multicolumn{2}{|c|}{ Control group } & \multicolumn{2}{|c|}{ ER group } & & & & \\
\hline & Mean & SEM & Mean & SEM & Control group & ER group & Control group & ER group \\
\hline 0 & 36.0 & 0.5 & 35.3 & $0.4^{\star \star}$ & - & - & - & - \\
\hline 1 & 74.8 & 1.4 & $50 \cdot 0$ & $1^{\star \star}$ & 15.4 & $5 \cdot 8$ & 83.17 & 42.5 \\
\hline 2 & $130 \cdot 3$ & $2 \cdot 2$ & 68.4 & $1.5^{\star *}$ & $10 \cdot 6$ & 5.4 & 123.5 & 46.92 \\
\hline 3 & 255 & 8 & 187 & $7^{\star *}$ & $13 \cdot 7$ & $24 \cdot 8$ & 343.7 & $322 \cdot 37$ \\
\hline 4 & 390 & 12 & 310 & $8^{\star *}$ & 7.6 & 9.4 & 293.75 & 244.74 \\
\hline 5 & 540 & 9 & 451 & $13^{\star \star}$ & 5.5 & 6.5 & $262 \cdot 82$ & 228.95 \\
\hline 6 & 732 & 13 & 622 & $15^{\star \star}$ & $5 \cdot 1$ & 5.4 & 431.79 & 374.21 \\
\hline 7 & 988 & 21 & 843 & $18^{\star \star}$ & $5 \cdot 0$ & $5 \cdot 1$ & 540.53 & $517 \cdot 89$ \\
\hline 8 & 1227 & 38 & 1062 & $25^{\star \star}$ & 3.4 & 3.7 & 652.63 & 507.89 \\
\hline 9 & 1402 & 43 & 1250 & $33^{*}$ & $2 \cdot 0$ & 2.5 & 458.95 & $463 \cdot 16$ \\
\hline
\end{tabular}

Mean values were significantly different from those from the control group of the same age: * $P<0.05,{ }^{\star *} P<0.01, n 20$.

but rose significantly during the first week of the subsequent $a d$ libitum feeding demonstrating a tendency of 'catch up' growth. However, this increased growth rate lasted only for one week and the relative growth rate declined to a level that is not different from the control group from the week. Accordingly, the weight of the lateral gastrocnemius muscle in the ER group was significantly lower both at 14 and $63 \mathrm{~d}$ of age (Fig. 1).

\section{Serum total thyroid hormone levels}

As shown in Fig. 2, both $\mathrm{T}_{3}$ and $\mathrm{T}_{4}$ levels decreased with age from $14 \mathrm{~d}$ to $63 \mathrm{~d}$, regardless of treatment. Chickens in the ER group exhibited markedly decreased serum concentrations of $\mathrm{T}_{3}$ and $\mathrm{T}_{4}$ at $14 \mathrm{~d}$, while at $63 \mathrm{~d}$, serum $\mathrm{T}_{3}$ remained low in the ER group but $\mathrm{T}_{4}$ restored to the level that was not different from the control.

\section{Morphology of the lateral gastrocnemius muscle}

Fig. 3 shows the morphological changes of the lateral gastrocnemius muscle from myosin ATPase staining. The lateral gastrocnemius muscle of the ER group possessed higher density of SM at $14 \mathrm{~d}$ with lower density at $63 \mathrm{~d}$ compared with the control group of the same age. The cross-sectional area of both FRM and FWM was significantly smaller in the ER group than that in the control group at $14 \mathrm{~d}$. At $63 \mathrm{~d}$, all three types of myofibres in the ER group were still smaller in size, but only the FWM maintained significantly lower cross-sectional area compared with that in the control (Table 4).

mRNA expression of different types of myosin heavy chain and growth-related genes in the lateral gastrocnemius

As shown in Fig. 4, the ER group expressed significantly higher SM $(P<0 \cdot 01)$, FRM MyHC $(P<0 \cdot 05)$ and IGF-IR $(P<0.01)$ but lower FWM MyHC $(P<0.05)$ and IGF-I $(P<0.01)$ mRNA in the lateral gastrocnemius muscle, compared with their control counterparts at $14 \mathrm{~d}$. At $63 \mathrm{~d}$ however, a significant down-regulation was observed in the ER group for SM MyHC expression $(P<0.05)$, accompanied by a significantly higher GHR $(P<0.05)$ and IGF-IR $(P<0.01)$
mRNA expression. Despite trends of decrease for FRM and numeric increase for FWM in the ER group, no significant differences were detected for either FRM or FWM MyHC mRNA expression between two groups (Fig. 5).

Correlations among body weight, the lateral gastrocnemius muscle weight and the expression of myosin heavy chain

The weight of the lateral gastrocnemius muscle significantly correlated with the body weight at both $14 \mathrm{~d}$ ( $r$ 0.962, $P<0.01)$ and $63 \mathrm{~d}(r 0.821, P<0.01)$. Muscle weight was found to be positively correlated with FWM MyHC expression ( $r 0.528, P<0.05$ ), but negatively correlated with SM MyHC expression $(r-0.526, P<0.05)$ at $14 \mathrm{~d}$. A moderate positive correlation $(r 0.504, P<0 \cdot 05)$ was observed between muscle weight and FRM MyHC expression at $63 \mathrm{~d}$.

\section{Discussion}

The present experiment demonstrated that nutritional deficiency during early post-hatch development induced permanent negative effect on body weight at slaughter in crossbred broiler chickens, which was in agreement with the previous findings in mice (Widdowson \& McCance, 1963) and broiler chickens (Maxwell et al. 1991).

The majority of studies in chicken describing the influence of feed restriction of different timing, period, or severity have been focused on growth and carcass characteristics (Camacho et al. 2004; Pinheiro et al. 2004; Hiramatsu et al. 2005). There are scarcely any data concerning the changes of muscle morphology and metabolic properties induced by feed restriction, in addition to changes of muscle weight (Brown et al. 1990). It is known that muscle fibre formation is completed late in gestation in mammals and at hatching in avian species; the postnatal muscle growth is determined by myofibre hypertrophy which is accompanied with myofibre-type transformation following the sequence: $\mathrm{SM} \rightarrow \mathrm{FRM} \rightarrow$ intermediate type myofibres $\rightarrow$ FWM in both mammal (Lefaucheur et al. 2004) and avian species (Gauthier et al. 1982; Tidyman et al. 1997; Rushbrook et al. 1998; Bandman \& Rosser, 2000). 
(a)
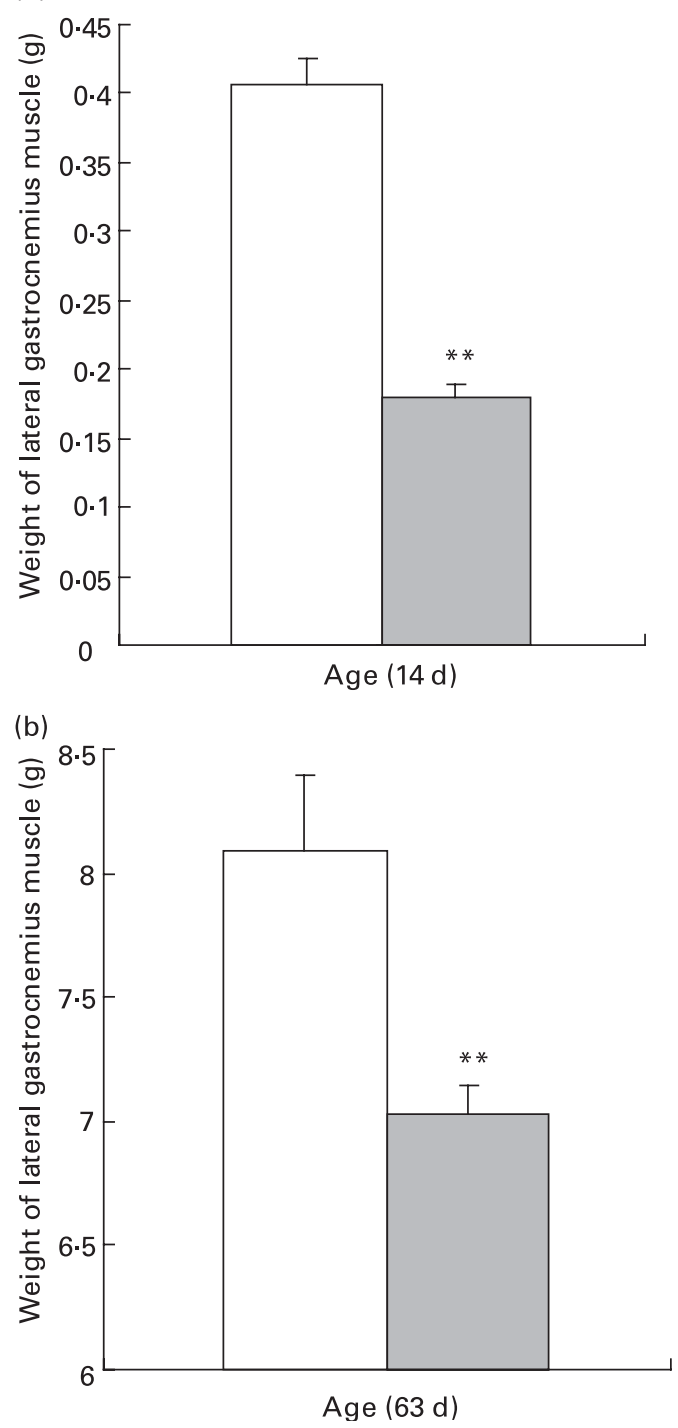

Fig. 1. Effect of early feed restriction (ER) on weight of the lateral gastrocnemius muscle from crossbred broiler chickens at age (a) 14 days and (b) 63 days. Values for the control ( $\square$ ) and the ER ( $\square$ ) group are given as means with their standard errors represented by vertical bars. Mean value was significantly different from that of the control group: ${ }^{\star \star} P<0.01, n 10$.

Traditionally myofibre typing of the skeletal muscle is achieved by using a morphological method (Hoogenraad et al. 1979; Wegner et al. 2000). Based on the knowledge that different types of myofibres express different MyHC that are encoded by respective genes (Chen et al. 1997; Rushbrook et al. 1998), a multiplex RT-PCR technique was developed for investigating myofibre-type composition based on the fibre-specific expression of different MyHC isoforms (Tanabe et al. 1998). This technique was employed in recent studies for typing porcine and bovine skeletal muscles (Muroya et al. 2002; Zhao et al. 2004b). The relative percentage of a specific myofibre type can be estimated by quantification of corresponding MyHC mRNA expressed in that muscle (Tidyman et al. 1997).

The transition of myofibre types depends on intrinsic programming related to the myoblast lineage from which (a)

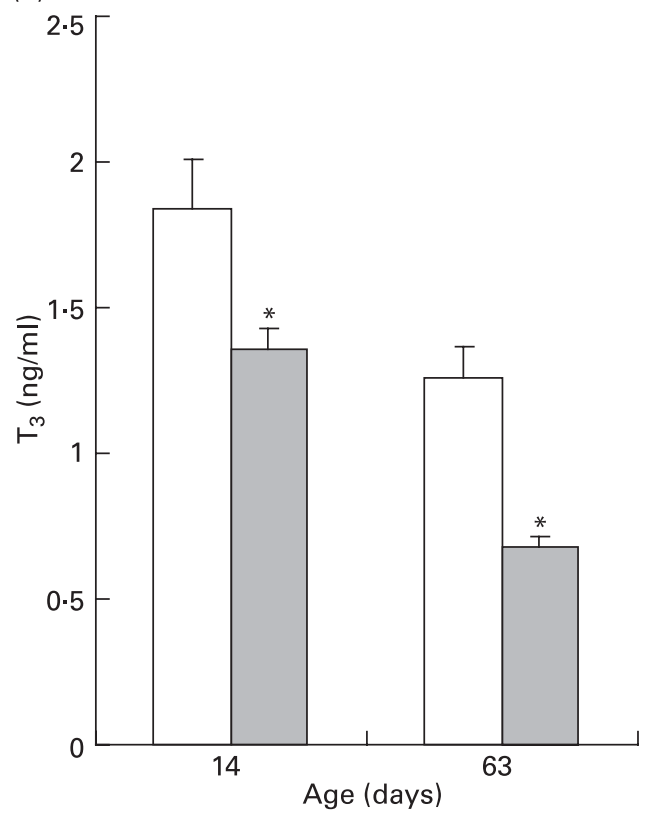

(b)

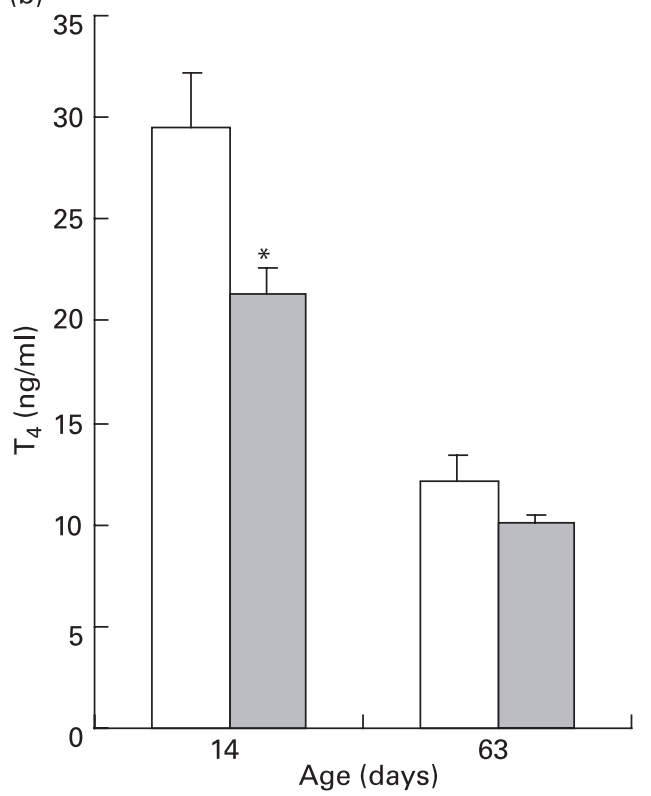

Fig. 2. Effect of early feed restriction (ER) on serum thyroid hormone $\left(T_{3}(a)\right.$ and $T_{4}(b)$ ) levels of crossbred broiler chickens. Values for the control $(\square)$ and the ER ( $\square$ ) group are given as means with their standard errors represented by vertical bars. Mean value was significantly different from that of the control group: * $P<0.05, n 10$.

muscle fibres develop and is further regulated by extrinsic influences such as neural, hormonal, dietary and mechanical factors including muscle activity (Vadaszova et al. 2004). It is reported that the conversion from embryonic myofibres to neonatal myofibres and adult myofibres would be delayed by muscular dystrophy (Tidyman et al. 1997). In the present study both morphological and molecular typing pointed to higher oxidative fibres (SM and FRM) and lower glycolytic fibres (FWM) in the ER group compared with their control counterparts immediately after feed restriction at $14 \mathrm{~d}$, 


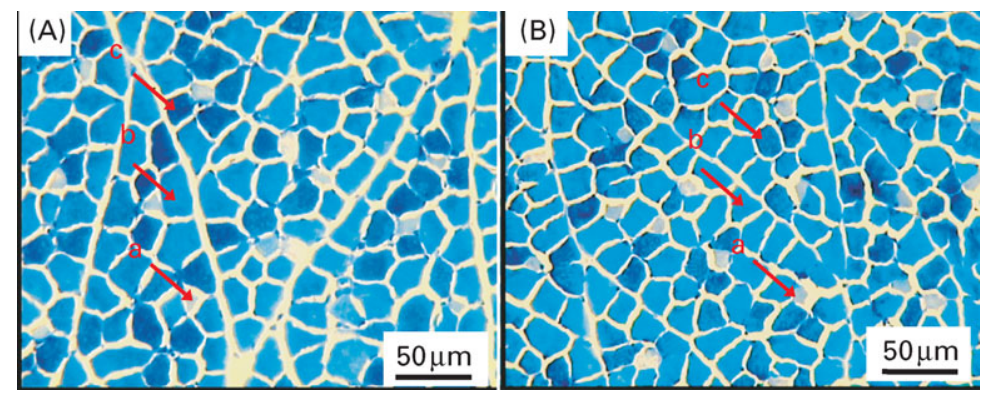

Fig. 3. Representative images of histochemical ATPase staining at magnification 200 for the lateral gastrocnemius muscle of crossbred broiler chickens from (A) the control group and (B) the early feed restriction group at 14 days of age showing a, slow-twitch myofibre; b, red fast-twitch myofibre, and c, white fast-twitch myofibre.

suggesting delayed or arrested conversion from SM to fast-twitch myofibre by feed restriction, even though the molecular typing by relative quantification of mRNA expression of three different MyHC did not completely match the result of morphological study due to differences in resolution and specificity of the two methods.

The pathway mediating the effect of nutritional deficiency on myofibre type transformation is not completely elucidated, yet reduced serum concentration of thyroid hormones was suggested to be involved in the mechanism (Gunning \& Hardeman, 1991; Dewil et al. 1999). Hypothyroidism leads to preferential expression of slower fibre types while hyperthyroidism enhances the content of fast fibres in rats (Vadaszova et al. 2004). Indeed, we detected significant reduction both for $\mathrm{T}_{3}(-26 \%)$ and $\mathrm{T}_{4}(-28 \%)$ serum concentrations in the ER group at $14 \mathrm{~d}$ (Fig. 2). In addition, morphological study revealed reduced cross-sectional area of all myofibre types in the ER group at $14 \mathrm{~d}$ compared with the control group, although the difference of slow fibres did not reach the statistically significant level. This result demonstrated that ER stunted the hypertrophy of myofibres in general regardless of fibre types, which may eventually result in reduced lateral gastrocnemius muscle weight and decreased body weight. Furthermore, higher proportion of slow fibres would contribute to lower muscle weight in the ER group, as indicated by the correlation analysis.

The influence of ER on the myofibre-type composition is long-lasting. To our surprise, however, the difference between the ER and the control group in myofibre-type composition at $63 \mathrm{~d}$ was in contrast to that observed at $14 \mathrm{~d}$. Both morphological and molecular typing showed lower SM in the ER group at $63 \mathrm{~d}$, with reduced cross-sectional area of all myofibre types in the ER group at $63 \mathrm{~d}$ compared with the control group, although only FWM reached the statistically significant level. This result demonstrated that ER may induce an accelerated myofibre hypertrophy in the long term.

The postnatal events contributing to myofibre hypertrophy comprise satellite cell proliferation, differentiation and protein turnover. Many studies indicate a possible role of a growth hormone $(\mathrm{GH}) / \mathrm{IGF}-\mathrm{I}$ system in the regulation of postnatal muscle growth (Oksbjerg et al. 2004). The feed restriction-induced reduction in body weight in chickens was accompanied by a significant fall in circulating IGF-I (Scanes \& Griminger, 1990; Morishita et al. 1993; Leili et al. 1997) and a rise in plasma GH (Krestel-Rickert et al. 1986; Kuhn et al. 1991), which are restored to the normal levels by refeeding (Kita et al. 1996; Maxwell et al. 1999). A recent study provided evidence that the in vivo effects of GH on muscle mass and strength are primarily mediated by activation of the IGF-I receptor in skeletal muscle, since mice lacking IGF-I function specifically in skeletal muscle, due to the over expression of a dominant-negative IGF-I receptor in this tissue (MKR mice) exhibited no effects of $\mathrm{GH}$ on the cross-sectional area of myofibres and the proliferation of satellite cells (Kim et al. 2005). The role of the GHIGF-I axis in the regulation of avian muscle growth is more vague and still under debate (Buyse \& Decuypere, 1999). It is suggested that in the chicken, hepatic expression of IGFI mRNA is GH-dependent after hatching, whereas IGF-I expression in other tissues, including muscle, is independent

Table 4. Effect of early feed restriction (ER) on morphology of the lateral gastrocnemius muscle (Values are means with their standard errors)

\begin{tabular}{|c|c|c|c|c|c|c|c|c|}
\hline \multirow[b]{3}{*}{ Parameters } & \multicolumn{4}{|c|}{$14 d$} & \multicolumn{4}{|c|}{$63 d$} \\
\hline & \multicolumn{2}{|c|}{ Control } & \multicolumn{2}{|c|}{ ER } & \multicolumn{2}{|c|}{ Control } & \multicolumn{2}{|c|}{ ER } \\
\hline & Mean & SEM & Mean & SEM & Mean & SEM & Mean & SEM \\
\hline Density of slow-twitch myofibres (\%) & 17.5 & 1.9 & 24.4 & $4 \cdot 1^{*}$ & 25.4 & $2 \cdot 9$ & $18 \cdot 0$ & $2 \cdot 2^{\star}$ \\
\hline Density of red fast-twitch myofibres (\%) & 53.0 & 4.6 & $47 \cdot 6$ & $6 \cdot 1$ & 23.2 & 1.7 & 27 & 11 \\
\hline Density of white fast-twitch myofibres (\%) & $29 \cdot 6$ & $4 \cdot 3$ & $28 \cdot 0$ & $4 \cdot 8$ & 51.4 & 3.4 & 55 & 11 \\
\hline Average cross-sectional area of slow-twitch myofibres $\left(\mu \mathrm{m}^{2}\right)$ & 142 & 50 & 118 & 15 & 1550 & 340 & 1020 & 310 \\
\hline Average cross-sectional area of red fast-twitch myofibres $\left(\mu \mathrm{m}^{2}\right)$ & 408 & 56 & 246 & $56^{*}$ & 2118 & 407 & 1690 & 180 \\
\hline Average cross-sectional area of white fast-twitch myofibres $\left(\mu \mathrm{m}^{2}\right)$ & 405 & 96 & 232 & $36^{*}$ & 2960 & 410 & 2160 & $160^{*}$ \\
\hline
\end{tabular}

Mean values were significantly different from those from the control group of the same age: * $P<0.05, n 6$. 


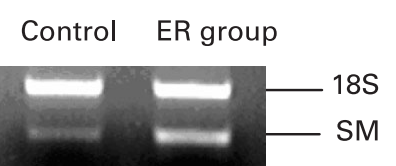

(a)

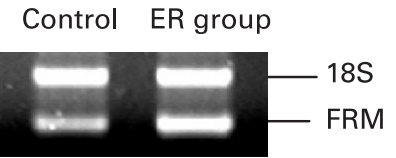

(b)

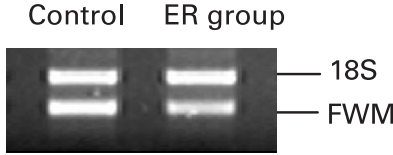

(c)

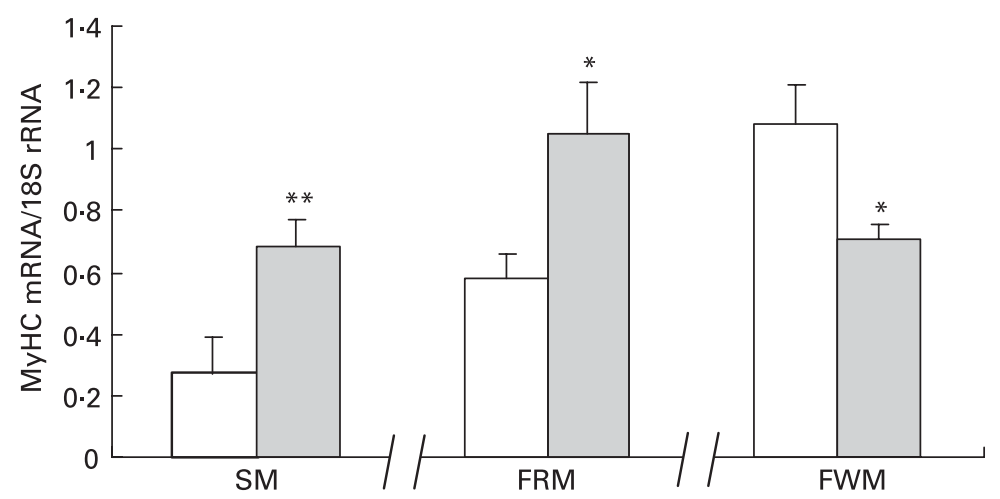

(d)

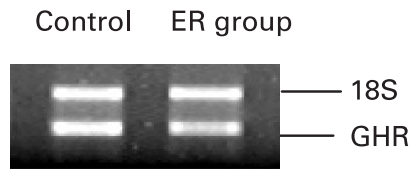

(e)

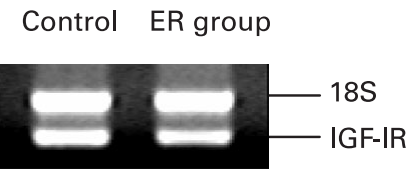

(f)

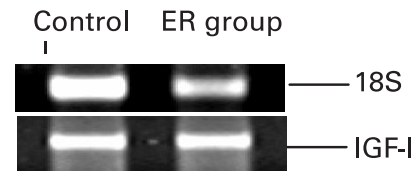

(g)

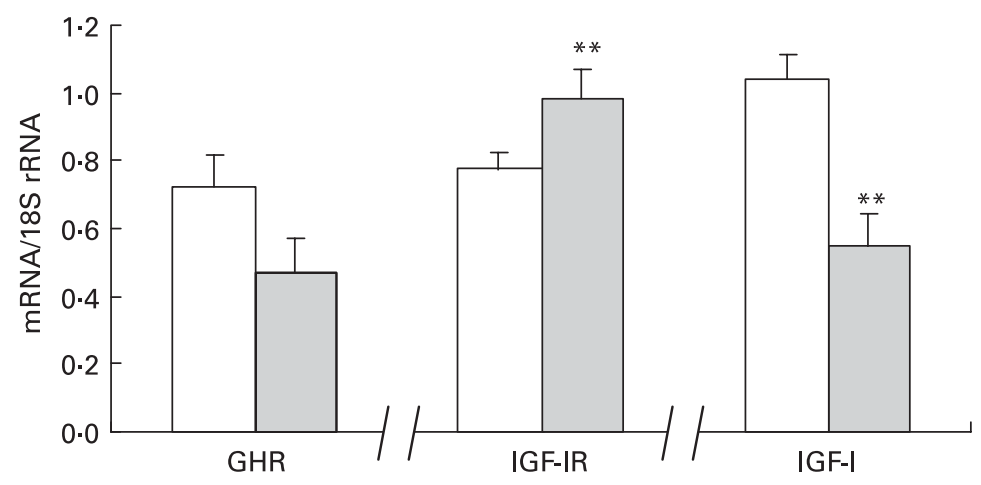

(h)

Fig. 4. Effect of early feed restriction (ER) on mRNA expression of myosin heavy chain (MyHC) and growth-related genes in the lateral gastrocnemius muscle of $14 \mathrm{~d}$ old crossbred broiler chickens. (a)-(c) Representative electrophoresis photos of RT-PCR products for slow-twitch myofibre (SM), red fast-twitch myofibre (FRM) and white fast-twitch myofibre (FWM) MyHC mRNA, co-amplified with 18S rRNA, respectively. (d) Results of statistical analysis for abundance of SM, FRM and FWM MyHC mRNA in the control ( $\square$ ) and the ER ( $\square$ ) group. (e)-(g) Representative electrophoresis photos of RT-PCR products for growth hormone receptor (GHR) and type 1 insulin-like growth factor receptor (IGF-IR), co-amplified with 18S rRNA, as well as insulin-like growth factor I (IGF-I) mRNA, amplified separately from 18S rRNA, respectively. (h) Results of statistical analysis for abundances of GHR, IGF-IR and IGF-I mRNA. mRNA levels of target genes are expressed as arbitrary units relative to 18S rRNA in the control ( $\square$ ) and the ER ( $\square$ ) group. Values are given as means with their standard errors represented by vertical bars. Mean value was significantly different from that of the control group: ${ }^{\star} P<0.05,{ }^{\star \star} P<0.01, n 10$.

of GH and GHR (Tanaka et al. 1996). The absence of a functional GHR in the dwarf chicken is associated with a greater decline in DNA synthesis but no alterations were observed in IGF-I mRNA or peptide in muscle (Goddard et al. 1996). In avian skeletal muscle satellite cells, GHR gene expression was regulated by $\mathrm{cGH}$ in a biphasic manner which correlated with the $\mathrm{GH}$ effect on cell proliferation: $2-10 \mathrm{ng}$ hormone/ml increased GHR mRNA and DNA synthesis, whereas higher concentrations attenuated these effects (Halevy et al. 1996). In the present experiment, delayed conversion from SM to fast-twitch myofibre and higher percentage of slow fibres in the ER group at $14 \mathrm{~d}$ was associated with significantly higher IGF-IR mRNA expression but lower IGF-I mRNA in the gastrocnemius muscle, while the lower percentage of SM and retarded hypertrophy in the ER group observed at $63 \mathrm{~d}$ was accompanied by significantly elevated GHR and IGF-IR mRNA expression. The higher muscle IGF-IR mRNA 


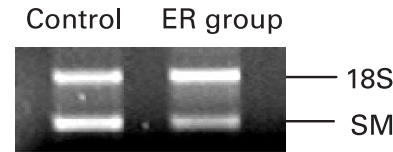

(a)

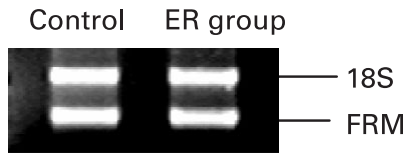

(b)

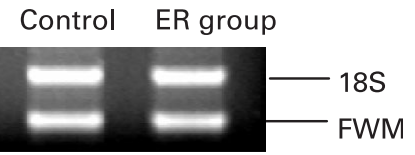

(c)

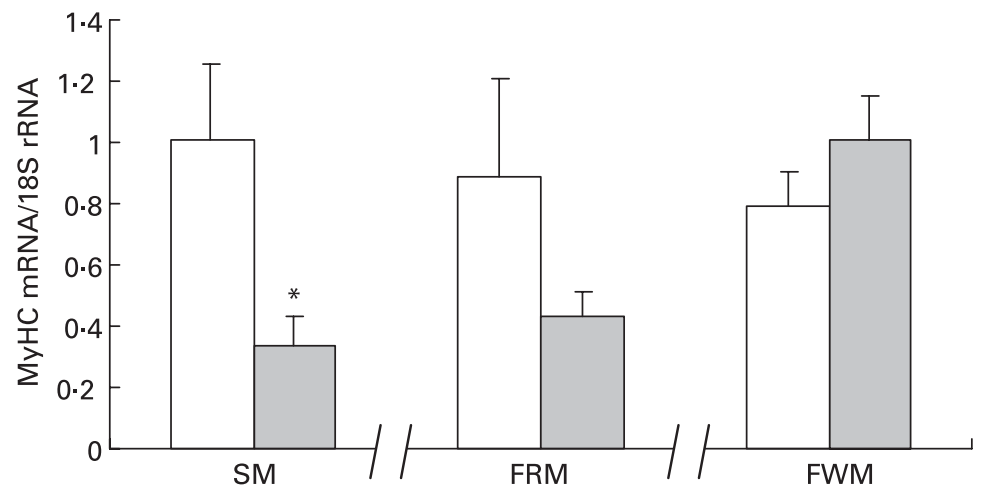

(d)

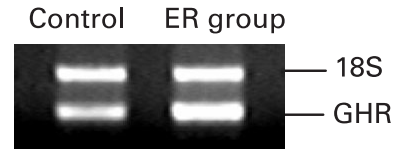

(e)

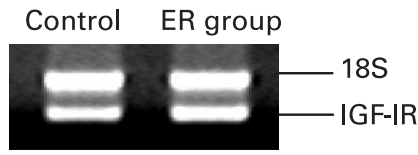

(f)

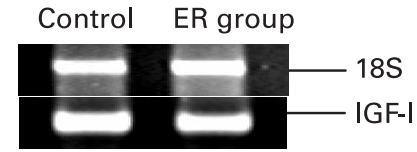

(g)

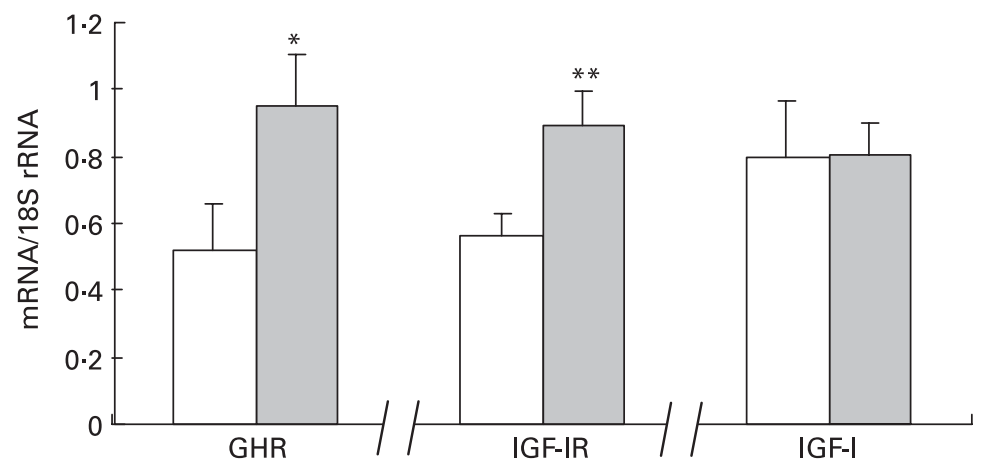

(h)

Fig. 5. Effect of early feed restriction (ER) on mRNA expression of myosin heavy chain (MyHC) and growth-related genes in the lateral gastrocnemius muscle of $63 \mathrm{~d}$ old crossbred broiler chickens. (a)-(c) Representative electrophoresis photos of RT-PCR products for slow-twitch myofibre (SM), red fast-twitch myofibre (FRM) and white fast-twitch myofibre (FWM) MyHC mRNA, co-amplified with 18S rRNA, respectively. (d) Results of statistical analysis for abundances of SM, FRM and FWM MyHC mRNA in the control $(\square)$ and the ER ( $\square$ ) group. (e)-(g) Representative electrophoresis photos of RT-PCR products for growth hormone receptor (GHR) and type 1 insulin-like growth factor receptor (IGF-IR), co-amplified with 18S rRNA, as well as insulin-like growth factor I (IGF-I) mRNA, amplified separately from 18S rRNA, respectively. (h) Results of statistical analysis for abundances of GHR, IGF-IR and IGF-I mRNA. mRNA levels of target genes are expressed as arbitrary units relative to 18S rRNA in the control $(\square)$ and the ER ( $\square$ ) group. Values are given as means with their standard errors represented by vertical bars. Mean value was significantly different from that of the control group: ${ }^{*} P<0.05,{ }^{* \star} P<0.01, n 10$.

expression at $14 \mathrm{~d}$ could be the consequence of decreased circulating and local level of IGF-I, as indicated by significantly decreased abundance of IGF-I mRNA in the muscle. The upregulated expression of both GHR and IGF-IR mRNA in the muscle at $63 \mathrm{~d}$ may reflect the physiological response of the muscle to the ER for a compensatory growth via accelerated myofibre hypertrophy. This adaptation mechanism failed to achieve the complete growth compensation by the end of the experiment, probably due to the limited time allowed for the 'catch-up' growth. However, it seems unlikely that the alterations in muscle morphology and metabolic properties as reflected by the change in myofibre-type composition would be restored even if chickens in the ER group attained normal body weight. This life-long effect of ER may thus induce changes in metabolic status and compromise meat quality in later life.

In conclusion, ER delays the myofibre conversion from slow-tonic to fast-twitch types, resulting in retarded muscle growth that may account for the decreased body weight. The influence of ER on myofibre types is long-lasting, significant differences still seen after 7 weeks when chickens reach the marketing age. Changes in muscle expression of 
GHR and IGF-IR mRNA may be involved in the acting mechanism.

\section{Acknowledgements}

This work was supported by National Basic Research Program of China (2004CB117505) and the Sino-German Cooperation in Agriculture, Project No. 17.

\section{References}

Acar N, Sizemore FG, Leach GR, Wideman RF, Owen RL \& Barbato GF (1995) Growth of broiler chickens in response to feed restriction regimens to reduce ascites. Poult Sci 74, 833-843.

Ashmore CR \& Doerr L (1971) Comparative aspects of muscle fiber types in different species. Exp Neurol 31, 408-418.

Bandman E \& Rosser BWC (2000) Evolutionary significance of myosin heavy chain. Microsc Res Techniq 50, 473-491.

Brown CR, Palmer WK \& Bechtel PJ (1990) Effects of food restriction on stretch induced muscle hypertrophy in chickens of various ages. Comp Biochem Physiol A 95, 321-324.

Buyse J \& Decuypere E (1999) The role of the somatotrophic axis in the metabolism of the chicken. Domest Anim Endocrinol 17, 245-255.

Camacho MA, Suarez ME, Herrera JG, Cuca JM \& Garcia-Bojalil CM (2004) Effect of age of feed restriction and microelement supplementation to control ascites on production and carcass characteristics of broilers. Poult Sci 83, 526-532.

Chen Q, Moore LA, Wick M \& Bandman E (1997) Identification of a genomic locus containing three slow myosin heavy chain genes in the chicken. Biochim Biophys Acta 1353, 148-156.

Chomczynski P \& Sacchi N (1987) Single-step method of RNA isolation by acid guanidinium thiocyanate-phenol-chloroform extraction. Anal Biochem 162, 156-159.

Deaton JW (1995) The effect of early feed restriction on broiler performance. Poult Sci 74, 1280-1286.

Demmelmair H, von Rosen J \& Koletzko B (2006) Long-term consequences of early nutrition. Early Hum Dev 82, 567-574.

de Moura EG \& Passos MC (2005) Neonatal programming of body weight regulation and energetic metabolism. Biosci Rep 25, $251-269$.

Dewil E, Darras VM, Spencer GS, Lauterio TJ \& Decuypere E (1999) The regulation of GH-dependent hormones and enzymes after feed restriction in dwarf and control chickens. Life Sci 64, 1359-1371.

Gauthier G, Lowey S, Benfield PA \& Hobbs AW (1982) Distribution and properties of myosin isozymes in developing avian and mammalian skeletal muscle fibers. J Cell Biol 92, 471-484.

Goddard C, Johnson R, Gilhooley HJ, Gardner JO, Gray A, Wilkie RS \& Butterwith SC (1996) Decreased muscle cell proliferation in chicks with a deletion in the GH receptor gene. $J$ Mol Endocrinol 17, 67-78.

Goerzen PR, Julsrud WL \& Robinson FE (1996) Duration of fertility in ad libitum and feed-restricted caged broiler breeders. Poult Sci 75, 962-965.

Gunning P \& Hardeman E (1991) Multiple mechanisms regulate muscle fiber diversity. FASEB J 5, 3064-3070.

Halevy O, Hodik V \& Mett A (1996) The effects of growth hormone on avian skeletal muscle satellite cell proliferation and differentiation. Gen Comp Endocrinol 101, 43-52.

Hickey MS, Carey JO, Azevedo JL, Houmard JA, Pories WJ, Israel RG \& Dohm GL (1995) Skeletal muscle fiber composition is related to adiposity and in vitro glucose transport rate in humans. Am J Physiol 268, E453-E457.

Hiramatsu K, Nagao K \& Kita K (2005) Localization of insulinlike growth factor I (IGF-I) in the chicken liver after fasting and refeeding: demonstration by using antigen retrieval immunohistochemistry. J Vet Med Sci 67, 393-397.

Hoogenraad TU, Jennekens FG \& Tan KE (1979) Histochemical fibre types in human extraocular muscles, an investigation of inferior oblique muscle. Acta Neuropathol (Berl) 45, 73-78.

Khajavi M, Rahimi S, Hassan ZM, Kamali MA \& Mousavi T (2003) Effect of feed restriction early in life on humoral and cellular immunity of two commercial broiler strains under heat stress conditions. Br Poult Sci 44, 490-497.

Kim H, Barton E, Muja N, Yakar S, Pennisi P \& Leroith D (2005) Intact insulin and insulin-like growth factor-I receptor signaling is required for growth hormone effects on skeletal muscle growth and function in vivo. Endocrinology 146, 1772-1779.

Kita K, Tomas FM, Owens PC, Knowles SE, Forbes BE, Upton Z, Hughes R \& Ballard FJ (1996) Influence of nutrition on hepatic IGF-I mRNA levels and plasma concentrations of IGF-I and IGF-II in meat-type chickens. J Endocrinol 149, 181-190.

Korach-Andre M, Gounarides J, Deacon R, Beil M, Sun D, Gao J \& Laurent D (2005) Age and muscle-type modulated role of intramyocellular lipids in the progression of insulin resistance in nondiabetic Zucker rats. Metabolism 54, 522-528.

Krestel-Rickert DH, Baile CA \& Buonomo FC (1986) Changes in insulin, glucose and GH concentrations in fed chickens. Physiol Behav 37, 361-363.

Kuhn ER, Herremans M, Dewil E, Vanderpooten A, Rudas P, Bartha T, Verheyen G, Berghman L \& Decuypere E (1991) Thyrotropin-releasing hormone (TRH) is not thyrotropic but somatotropic in fed and starved adult chickens. Reprod Nutr Dev 31, 431-439.

Kwakkel RP, Hof G, Zandstra T \& Ducro BJ (1998) Diphasic allometric growth of some skeletal bones and the digestive tract in White Leghorn pullets consuming ad libitum and restricted diets. Poult Sci 77, 826-833.

Langley-Evans SC, Bellinger L \& McMullen S (2005) Animal models of programming: early life influences on appetite and feeding behaviour. Matern Child Nutr 1, 142-148.

Lee KH \& Leeson S (2001) Performance of broilers fed limited quantities of feed or nutrients during seven to fourteen days of age. Poult Sci 80, 446-454.

Lefaucheur L, Milan D, Ecolan P \& Le Callennec C (2004) Myosin heavy chain composition of different skeletal muscles in Large White and Meishan pigs. J Anim Sci 82, 1931-1941.

Leili S, Buonomo FC \& Scanes CG (1997) The effects of dietary restriction on insulin-like growth factor (IGF)-I and II, and IGFbinding proteins in chickens. Proc Soc Exp Biol Med 216, 104-111.

Maltin C, Balcerzak D, Tilley R \& Delday M (2003) Determinants of meat quality: tenderness. Proc Nutr Soc 62, 337-347.

Maxwell A, Butterwick R, Batt RM \& Camacho-Hubner C (1999) Serum insulin-like growth factor (IGF)-I concentrations are reduced by short-term dietary restriction and restored by refeeding in domestic cats (Felis catus). J Nutr 129, 1879-1884.

Maxwell MH, Robertson GW, Anderson IA, Dick LA \& Lynch M (1991) Haematology and histopathology of seven-week-old broilers after early food restriction. Res Vet Sci 50, 290-297.

Moore DT, Ferket PR \& Mozdziak PE (2005a) Early post-hatch fasting induces satellite cell self-renewal. Comp Biochem Physiol A Mol Integr Physiol 142, 331-339.

Moore DT, Ferket PR \& Mozdziak PE (2005b) The effect of early nutrition on satellite cell dynamics in the young turkey. Poult Sci 84, 748-756.

Morishita D, Sasaki K, Wakita M \& Hoshino S (1993) Effect of fasting on serum insulin-like growth factor-I (IGF-I) levels and IGF-I-binding activity in cockerels. J Endocrinol 139, 363-370.

Muroya S, Nakajima I \& Chikuni K (2002) Related expression of MyoD and Myf5 with myosin heavy chain isoform types in bovine adult skeletal muscles. Zoolog Sci 19, 755-761. 
Oksbjerg N, Gondret F \& Vestergaard M (2004) Basic principles of muscle development and growth in meat-producing mammals as affected by the insulin-like growth factor (IGF) system. Domest Anim Endocrinol 27, 219-240.

Palo PE, Sell JL, Piquer FJ, Soto-Salanova MF \& Vilaseca L (1995a) Effect of early nutrient restriction on broiler chickens. 1. Performance and development of the gastrointestinal tract. Poult Sci 74, 88-101.

Palo PE, Sell JL, Piquer FJ, Vilaseca L \& Soto-Salanova MF (1995b) Effect of early nutrient restriction on broiler chickens. 2. Performance and digestive enzyme activities. Poult Sci $\mathbf{7 4}$, $1470-1483$.

Pinheiro DF, Cruz VC, Sartori JR \& Vicentini Paulino ML (2004) Effect of early feed restriction and enzyme supplementation on digestive enzyme activities in broilers. Poult Sci 83, 1544-1550.

Rushbrook JI, Huang J, Weiss C, Yao TT, Siconolfi-Baez L \& Becker E (1998) Protein and mRNA analysis of myosin heavy chains in the developing avian pectoralis major muscle. J Muscle Res Cell Motil 19, 157-168.

Scanes CG \& Griminger P (1990) Endocrine-nutrition interactions in birds. J Exp Zool Suppl 4, 98-105.

Su G, Sorensen P \& Kestin SC (1999) Meal feeding is more effective than early feed restriction at reducing the prevalence of leg weakness in broiler chickens. Poult Sci 78, 949-955.

Tanabe R, Muroya S \& Chikuni K (1998) Sequencing of the 2a, 2x, and slow isoforms of the bovine myosin heavy chain and the different expression among muscles. Mamm Genome 9, $1056-1058$.

Tanaka M, Hayashida Y, Sakaguchi K, Ohkubo T, Wakita M, Hoshino S \& Nakashima K (1996) Growth hormone-independent expression of insulin-like growth factor I messenger ribonucleic acid in extrahepatic tissues of the chicken. Endocrinology 137, 30-34.
Tidyman WE, Moore LA \& Bandman E (1997) Expression of fast myosin heavy chain transcripts in developing and dystrophic chicken skeletal muscle. Dev Dynam 208, 491-504.

Vadaszova A, Zacharova G, Machacova K, Jirmanova I \& Soukup T (2004) Influence of thyroid status on the differentiation of slow and fast muscle phenotypes. Physiol Res 1, Suppl, S57-S61.

Wegner J, Albrecht E, Fiedler I, Teuscher F, Papstein HJ \& Ender K (2000) Growth- and breed-related changes of muscle fiber characteristics in cattle. J Anim Sci 78, 1485-1496.

Widdowson EM \& McCance RA (1963) The effect of finite periods of undernutrition at different ages on the composition and subsequent development of the rat. Proc R Soc Lond B Biol Sci 158, 329-342.

Wu G, Bazer FW, Wallace JM \& Spencer TE (2006) Board-invited review: intrauterine growth retardation: implications for the animal sciences. J Anim Sci 84, 2316-2337.

Zhao R, Wang Y, Zhou Y, Ni Y, Lu L, Grossmann R \& Chen J (2004a) Dietary daidzein influences laying performance of ducks (Anas platyrhynchos) and early post-hatch growth of their hatchlings by modulating gene expression. Comp Biochem Physiol A Mol Integr Physiol 138, 459-466.

Zhao RQ, Yang XJ, Xu QF, Wei XH, Xia D \& Chen J (2004b) Expression of GHR and PGC-1alpha in association with changes of $\mathrm{MyHC}$ isoform types in longissimus muscle of Erhualian and Large White pigs (Sus scrofa) during postnatal growth. Animal Science 79, 203-211.

Zhong C, Nakaue HS, Hu CY \& Mirosh LW (1995) Effect of full feed and early feed restriction on broiler performance, abdominal fat level, cellularity, and fat metabolism in broiler chickens. Poult Sci 74, 1636-1643. 